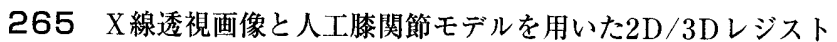
レーション一実画像による精度評価一

大阪大学大学院・医学系研究科器官制御外科学山崎隆治, 渡邉 哲, 菅本一臣，吉川秀樹

大阪大学大学院·医学系研究科多元的画像解析分野 中島義和 田村進一

大阪大学医学部附属病院・放射線部 前田大助

【目的】人工膝関節の 3 次元動態計測に関する研究では，近年，X線

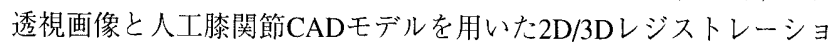
ン手法の適用が主流となっている。従来では，レジストレーション 精度は,コンピュータシミュレーションにより検証されていたが, 実際の透視画像を用いた評価は十分に達成されていなかった，本研 究では, 実際のX線透視装置を用い, 各コンポーネントのレジスト レーションの精度評価を行う。

【方法】精度評価の基準となる大腿骨・脛骨コンポーネントの姿勢決 定には, 赤外線LEDマーカーを計測可能な光学式3Dディジタイザ （精度：0.1mm）を用いた。まず，LEDマーカーを固定した人工滕関 節モデルをX線透視撮影空間に任意の姿勢で配置し，位置計測を 行った。次に, 計測された姿勢にてX線画像を取得し, 画像の歪み 補正，輪郭抽出処理を行ったあと，2D/3Dレジストレーションによ り各コンポーネントの姿勢推定を行った。 レジストレーション精度 は，それら計測值と推定值を比較して求めた。

【結果】各コンポーネントの精度は, 画像面内 $(\mathrm{X}, \mathrm{Y})$ の平行移動成分 が約 $0.1 \mathrm{~mm}$ に対し，画像面外 $(\mathrm{Z})$ の成分は約 $1.5 \mathrm{~mm}$ であった。 また， 回転成分は, 大腿骨コンポーネントがX, Y, Z軸に関して約 $0.1^{\circ}$, $0.1^{\circ} ， 0.6^{\circ}$ に対し, 脛骨コンポーネントは $0.2^{\circ}, 0.7^{\circ}, 0.1^{\circ}$ であった。

【考察】平行移動成分Zの精度結果は, 単面X線画像の使用によるもの で，各コンポーネントの回転成分の相違は，形状依存によるものと 考えられる。しかしながら, 実画像を用いたレジストレーション精 度は，動態解析を行う上で十分であった。

266 動画像認識を応用したX線透視画像の運動解析ソフトウエア の開発 (食道透視画像での検討) 第 2 報

東京都立保健科学大学 中屋健太郎，妹尾淳史

千葉大大学院·自然科学研究科 野村行弘

【目的】食道造影検査は診断が非常に困難であり，医師の技術や経験 に依存せざるをえない，近年，食道造影検査ではディジタルX線透 視装置による診断が普及してきた。しかし，現在のところ汎用的な 動態解析ソフトが開発されていない。昨年, 動画像認識を用いて食 道透視画像の運動解析し，動きを可視化するソフトの開発について 報告したが，解析ツールとしての機能がそしく沉用性に欠けるとい う問題点があった，今回我々は，解析ツールとして関心領域 $(\mathrm{ROI})$ を設定し，その領域の解析を可能にする機能を開発した解析ソフト に追加し，良好な解析結果が得られたのでこれを報告する。

【方法】解析アルゴリズムはオプテイカルフローの代表格である勾配 法を用いた．解析は沉用性の高いWindows 2000 (Microsoft社) のPC上 に解析ソフトIDL6.0 (RSI社)を用いて開発した. GUI上でディジタル X線透視画像を読み込み，運動解析を行った。動きの向きを矢印 で，大きさをグレイスケールで表示を行い，解析結果をファイルに 保存できるようプログラムを改良した。 また，ROIを設定して元画 像加抽出し, 抽出領域に限局した運動解析を可能にする機能を加 えた。さらに，ファントムを用いた精度評価も行った。

【結果および考察】今回我々が開発した解析ソフトの改良点として, 解析結果をファイルに保存することや，ROIに限局した動態解析が できるなどのいくつかの機能を追加したため，沉用性が向上した。 また，ファントムを用いた精度評価から実用上問題のない精度が得 られた。今後は症例の検討を行いながらさらに解析りフトの改良を 行っていきたい.
267 透視画像におけるマイクロカテーテルトラッキング手法 金沢大学・医学部保健学科 武村哲浩, 鈴木正行

Toshiba Stroke Research Center. Dept. of Neurosurgery. University at Buffalo R. Hoffmann Kenneth

大阪大学・医学部保健学科 原内 -

【目的】脳動脈を対象としたVascular IVRにおいて，マイクロカテー テルなどのデバイスの体内での 3 次元的位置情報を提供することで IVR手技を支援しようとする研究のため，我々は透視画像中のマク ロカテーテル先端位置をトラッキングする手法を開発した。

【方法】積和差分法を応用した手法を前のフレームでの先端位置を中 心とする局所に対し処理し，テンプレートマッチングにより検出し ていく手法を開発した，最初のマイクロカテーテル先端の位置は手 動で入力する必要がある．頭部ファントムと内䅡動脈を模したファ ントム, マイクロカテーテル (2.5Fr, Fastrack-18 Infusion Catheter, Target, USA)を用い, アンギオ装置CAS-8000(Toshiba America Medical Systems, Inc., USA)にてマイクロカテーテル動かしながら30f/ Sパルス透視 $(94 \mathrm{kV}, 50 \mathrm{~mA}, S S D 100 \mathrm{~cm}$, I.I.視野 $7 \mathrm{inch}$, 撮影時間 $3 \mathrm{sec})$ にて撮影した．得られた透視画像 $(1024 \times 1024 \times 16 \mathrm{bit}, 0.174 \mathrm{~mm} /$ pixel）90枚を用い，開発した手法の精度を測定した。精度は，全フ レームでのカテーテル先端位置を手動により求め，そこからの位置 的誤差を評価した。

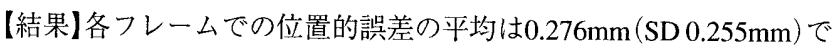
あった。誤差 $0.521 \mathrm{~mm}$ (3 pixels)未満となるフレームの割合は約 $92 \%$ であった。

【まとめ透視画像中のカテーテル先端位置を精度良くトラッキング する手法を開発できた。

\section{8 心カテ動画像における圧縮に関する基礎的検討}

名古屋大学・医学部保健学科 安藤剛一, 小寺吉衞

静岡県立総合病院 土屋裕一郎

名古屋大学大学院 - 医学系研究科 宮尾 雄, 高村美穂, 堀井亜希子 安田成臣

【目的】PACSの導入により，心臓血管造影のような動画像を院内ネッ トワークで閲覧することが可能となる。このとき動画像の画質を 保って圧縮すれば，低い伝達速度のネットワーク環境においても参 照用動画像として素早く閲覧することができのるではないかと考え た。そこで，高圧縮かつ画質が良いとされるDivXやWMV9 (Windows Media Video)に注目し，心臓血管造影のディジタル動画像 をいくつかの形式に圧縮して，一対比較法を用いて圧縮動画像の特 性などを検討した。

【方法】まずDICOM動画像(頻脈様動画像, 徐脈様動画像, 冠動脈狭 窄を含む動画像)をDICOMビューアkada-vew(フォトロン社)にて非 圧縮AVIに変換する．次に，シェアウェアのTMPGEnc 3.0 XPress (ペ ガシス社)を使用して非圧縮AVIから, MPEG (CBR), DivX (VBR), WMV9(CBR), WMV9-VCM(CBR)に, 同一フレームレート (15fps or 30fps)，同一画素(512×512)で揃えてそれぞれ圧縮する．同一ビッ トレートに圧縮した動画像を用いて一対比較法を行い，評価し検討 する. ※CBR：固定ビットレート, VBR：変動ビットレート

【結果】頻脈椂動画像, 徐脈様動画像, 冠動脈狭窄を含む動画像につ いて，それぞれ最適圧縮率が異なることがわかった，現時点で検討 数は少ないが同一ビットレートではMPEG, WMV9の結果が良く, WMV9-VCMとDivXではブロックノイズの影響が出ているため低い 評価となった。 